\title{
GDB - Human Genome Database Final Report
}

\author{
Final Report \\ For Period September 13, 1991 - August 31, 1999 \\ C. Conover Talbot Jr. \\ The Johns Hopkins University \\ School of Medicine \\ 720 Rutland Avenue DOE Patent Clearance Granted \\ Baltimore, MD 21205-4196 Muluf Dvorsule $\quad a_{p}$ i $\frac{2002}{\text { Ddte }}$ \\ Mark P Dvorscak \\ (630) 252-2393 \\ mail. mark.dvorscak@ch.doe.gov \\ Office of intellectual Property Law \\ Office of intelleclual Potions Office
}

January 2002

Prepared for

THE U.S. DEPARTMENT OF ENERGY

AWARD NO. DE-FC02-91ER61230

\section{NOTICE}

This report was prepared as an account of work sponsored by the United States Government. Neither the United States nor the United States Department of Energy, nor any of their employees, makes any warranty, express or implied, or assumes any legal liability or responsibility for the accuracy, completeness, or usefulness of any information, apparatus, product or process disclosed or represented that its use would not infringe privately-owned rights. 


\section{DISClaIMER}

This report was prepared as an account of work sponsored by an agency of the United States Government. Neither the United States Government aor any agency thereof, nor any of their employees, makes any warranty, express or implied, or assumes any legal liability or responsibility for the accuracy, completeness, or usefulness of any information, apparatus, product, or process disclosed, or represents that its use would not infringe privately owned rights. Reference herein to any specific commercial product, process, or service by trade name, trademark, manufacturer, or otherwise does not necessarily constitute or imply its endorsement, recommendation, or favoring by the United States Government or any agency thereof. The views and opinions of authors expressed herein do not necessarily state or reflect those of the United States Government or any agency thereof. 


\section{DISCLAIMER}

Portions of this document may be illegible in electronic image products. Images are produced from the best available original document. 
GDB - Human Genome Database

P.I.: Conover Talbot Jr.

Project Period: 9/13/1991 - 8/31/1999

The Johns Hopkins University

School of Medicine

720 Rutland Ave.

Baltimore MD 21205-2196

Cooperative Agreement \#DE-FC02-91ER61230

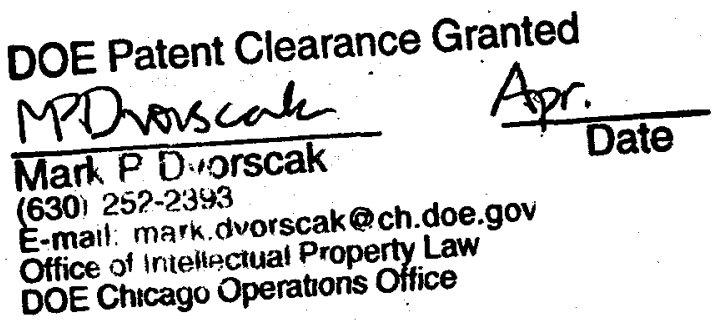

The Human Genome Database (GDB) project at the Johns Hopkins University (JHU) was established in cooperation with the U.S. Department of Energy (DOE) to create and maintain a system to collect, store, and present human genomic information in support of the Human Genome Project (HGP). These data concern genes, genetic disorders, clones, genetic markers and other loci together with their associated polymorphism, mapping and bibliographic information. The goals of this project included the assembly of a consensus view of all available data and the utilization of the best available technology to provide free access to the entire human genome research community.

The GDB Project goals have been fulfilled, and a comprehensive online database system was created, loaded with curated information, and is in place at this time. A complete financial report is attached to this overview. Following the termination of DOE funding, other financial support was secured through the generous support of an anonymous Canadian donor and physical service of the database was transferred from JHU to the Hospital for Sick Children (HSC) in Toronto Canada. Curation takes place at both JHU and HSC, in addition to GDB's Community Curation system (see below), and GDB remains the most extensive curated database of human genome information. It is the sole single source of polymorphism data on human markers and genes, and is the source of the universally accepted $D$-number nomenclature for human markers. At this time, GDB's Central Node in Toronto averages approximately 200,000 Web hits per week.

GDB derives its data from the widest possible sources, and its ruling authority has always been the Human Genome Organisation, HUGO. Large genome centers, e.g. the Whitehead Institute, as well as individual investigators have contributed their information either in bulk or via GDB's innovative Community Curation project. In 1996 GDB began providing investigators no-cost editing accounts with which they are able to enter and edit their own data and make annotation to the data of others. This system is unique to date and has been particularly successful in allowing authors to obtain the accession and "D-numbers" required for journal publication, and to hold their data private during 
the review process. A literature scanning program at JHU reviews the scientific literature and enters citations and their data into GDB. HUGO-appointed editors have served as GDB's authority for nomenclature and conflicting data. While GDB presents all known literature aliases and (even contradictory) map positions, 'HUGO approval' indicates their expert review. All data and observations are associated with their sources, be they institutional or individual.

Throughout this project, GDB has employed the best available technology to provide its users an encyclopedic view of genomic information. From its inception until 1994 GDB used the Internet's telnet function as its primary means of access. Users and editors required their own Internet accounts, and were provided with login information to access a text-based interface. With the creation of the World Wide Web, GDB inaugurated a 'Web' interface that allowed access to all; login accounts were required only for editing. All GDB's data are linked in a common structure so that users can proceed in an intuitive fashion, e.g. from a gene to its polymorphisms to the probes used to detect the polymorphisms, or from a bibliographic citation to all its associated information.

Prior to GDB genomic data were maintained in flat-file databases such as the Human Gene Mapping Library at Yale. While the Sybase database system continued to provide the underlying data tables, GDB has had 2 major schema versions. Releases 1 through 5 were designed on a straightforward relational model and were strictly textbased. The better to keep up with the rapidly changing nature of the HGP, GDB's 1996 release of version 6.0 adopted an object-oriented paradigm, based on the Object-Protocol Model created by Victor Markowitz, together with a completely revised Genera Web interface. Since version 6, GDB has incorporated the interactive graphic display of appropriate data. Maps can be viewed with the first Java-based map display tool, Mapview, and GDB's e-PCR query tool presents a graphic display of the input sequence and its associated PCR markers or amplimers. Wherever possible, GDB provides Web hypertext links between its data and their original source(s) in the literature and at laboratories, genome centers, and other databases. Likewise, links are provided to associated data sources, e.g. from GDB genes to locus-specific databases and to database entries for orthologous genes from other species.

In addition to its editable Central Node in North America, GDB has an international system of Mirror Nodes (including that at DOE's Oak Ridge National Laboratory), which provide both database access and user support to their respective communities. Academic institutions around the world maintain these read-only copies and update them nightly via ftp. Help line e-mail queries are directed to the curation center at JHU, where they are either answered or forwarded to the appropriate Mirror Node. The Nodes' role of speeding access is undiminished, notwithstanding a continuous increase in the Internet's speed, because of the Web's increased utilization and the increasingly graphic nature of GDB's data. In an era of increasing globalization of the HGP, it is perhaps of greater importance that these nodes enable GDB to provide support in the local language and time zone. 